Volume 13 Nomor 1, November 2021, p. 097-112.

Faculty of Law, Universitas Kristen Maranatha

ISSN: 2085-9945 I e-ISSN: 2579-3520

Nationally Accredited Journal by SINTA

\title{
PENERAPAN PRINSIP BUSINESS JUDGEMENT RULE TERHADAP DIREKSI ATAS PERBUATAN MELAWAN HUKUM KARYAWAN KARENA MENETAPKAN DISKON PEMBELIAN EMAS ANTAM SECARA SEPIHAK
}

\author{
Indriyani Kusumawati, Yeti Sumiyati \\ Master of Law Universitas Islam Bandung \\ indriyanikusumawati67@gmail.com
}

Submitted: 2021-08-12 | Reviewed: 2021-09-12 | Accepted: 2021-11-08

How to cite: Indriyani Kusumawati dan Yeti Sumiyati. "Penerapan Prinsip Business Judgement Rule Terhadap Direksi Atas Perbuatan Melawan Hukum Karyawan Karena Menetapkan Diskon Pembelian Emas Antam Secara Sepihak". Dialogia Iuridica: Jurnal Hukum Bisnis dan Investasi, Vol. 13, No. 1, (2021), 097-112.

DOI:

https://doi.org/10.28932/di.v13i1.3880

\section{ABSTRACT}

Unlawful acts cannot be separated by a violation of one's rights. This research is based on the phenomenon of directors who are penalized for unlawful acts committed by their employees. In 2021, PT Antam appealed to the court because the board of directors felt aggrieved by the judge's decision to impose damages on the directors of PT Antam. In fact, those who do illegal acts to the detriment of consumers are Eksi Anggraeni and the two employees, Misdianto and Ahmad Purwanto through the lure of discounts without the approval of the company. Limited Liability Companies Law implicitly regulates the concept of legal protection that is already known in some countries, namely the principle of Business Judgement Rule. This principle can be used by directors as a basis for legal protection to achieve justice. Therefore, the purpose of this research is to comprehend the responsibility of the board of directors for actions against employee law that stipulates discounts on the purchase of Antam gold unilaterally associated with the law of limited liability companies and review the application of the principles of Business 
Judgement Rule to directors who must be responsible for actions against the law of employees. The results of this study concluded that the directors of PT Antam cannot be held accountable. Furthermore, the application of the Business Judgement Rule principle has not been applied to this case, so legal protection to the board of directors is still ignored by the judge and has not shown justice.

Keywords: Board of Directors, Business Judgement Rule Principles, Unlawful Conduct

\section{PENDAHULUAN}

Prinsip Business Judgement Rule adalah suatu prinsip yang menjadi syarat untuk menakar pertanggungjawaban setiap anggota direksi. Pengetahuan akan prinsip Business Judgement Rule dan tata cara implementasinya oleh penegak hukum di Indonesia dirasa kurang. Sehingga, masih ada kasus yang ditegakkan berkaitan dengan kebijakan dan keputusan direksi beserta jajarannya, tanpa mempertimbangkan keberadaan akan prinsip Business Judgement Rule. ${ }^{1}$ Keberadaan prinsip Business Judgement Rule tersirat dalam Undang-Undang Nomor 40 Tahun 2007 tentang Perseroan Terbatas. ${ }^{2}$ Pengurusan Perseroan oleh Direksi tidak dapat dimintakan pertanggungjawaban selama dilakukan sesuai dengan kebijakan yang dipandang tepat, dalam batas yang ditentukan dalam undang-undang dan/ atau Anggaran Dasar/Anggaran Rumah Tangga Perusahaan Terbatas (selanjutnya disebut AD/ART PT) dengan iktikad baik dan penuh tanggung jawab. ${ }^{3}$

Suatu PT memiliki beberapa organ yaitu Rapat Umum Pemegang Saham (selanjutnya disebut RUPS), direksi, dan dewan komisaris. Perseroan Terbatas sebagai subjek hukum mandiri adalah artificial person, sesuatu yang tidak nyata. Untuk dapat bertindak dalam hukum, PT dijalankan oleh organ-organ yang akan bertindak mewakili PT tersebut yang membutuhkan direksi sebagai wakilnya. Dapat dikatakan bahwa perseroan terbatas tidak dapat berfungsi menjalankan hak dan kewajibannya tanpa bantuan direksi. ${ }^{4}$ Dengan kata lain, direksi melakukan segala tindakan pengurusan mulai dari mengelola perusahaan, mengurus kepemilikan kekayaan perusahaan, dan memiliki kontrol untuk mengawasi karyawannya.

\footnotetext{
${ }^{1}$ Lestari R, et.al, "Konsistensi Pengukuhan Kedudukan Kekayaan Negara Yang Dipisahkan Pada Badan Usaha Milik Negara Menurut Pelaku Kekuasaan Kehakiman Dalam Kaitannya Dengan Doktrin Business Judgement Rule", ACTA DIURNAL Jurnal Ilmu Hukum Kenotariatan, Vol. 1 No. 2, 2018, hlm. 247.

${ }^{2}$ Selanjutnya disingkat UUPT

${ }^{3}$ Isfardiyana, "Business Judgement Rule Oleh Direksi Perseroan", Jurnal Panorama Hukum, Vol. 2 No. 1, 2017, hlm. 19.

${ }^{4}$ Gunawan Widjaja, 150 Tanya Jawab tentang Perseroan Terbatas, Jakarta: Forum Sahabat, 2008, hlm. 3.
} 
Berelasi dengan argumentasi di atas, tidak semua kesalahan karyawan serta merta langsung dibebankan kepada direksi. Apabila kesalahan karyawan secara mudah dibebankan kepada direksi dapat membuat perusahaan bangkrut atau terjadinya penurunan kredibilitas pada perusahaan. Terutama jika kesalahan karyawan bukan atas perintah perusahaan, sudah seharusnya direksi terbebas dari tanggung jawab hukum. Merujuk pada Pasal 92 Ayat (1) dan Pasal 97 Ayat (2),(3),(5) UUPT, direksi dilindungi dari segala pertanggungjawaban atas tindakan yang dapat menimbulkan kerugian bagi perseroan dengan syarat-syarat tertentu.

Dalam kenyataannya, ditemukan fakta bahwa direksi harus membayar ganti rugi bukan karena kesalahan atau kelalaiannya. Tepatnya pada direksi PT. Antam yang dimintai pertanggungjawaban akibat kesalahan karyawan. Hal ini terjadi karena adanya penawaran diskon secara sepihak tanpa adanya persetujuan dari perusahaan. Penawaran diskon penjualan emas PT. Antam yang dilakukan oleh Eksi Anggraeni selaku broker kepada Budi Said selaku konsumen. Perbuatan Eksi Anggraeni dilakukan tidak hanya sendirian, melainkan bekerja sama dengan dua oknum karyawan bernama Misdianto dan Ahmad Purwanto selaku karyawan di cabang PT. Antam tepatnya di cabang Butik Emas Logam Mulia Surabaya Antam. ${ }^{5}$ Akibat kejadian tersebut, Budi Said merasa dirugikan dan mengajukan gugatan ke Pengadilan Negeri Surabaya. Hasil putusan Pengadilan Negeri Surabaya mengabulkan gugatan Budi Said dan menyatakan bahwa PT. Antam bertanggung jawab atas tindakan karyawannya di kantor Surabaya. PT. Antam pun merasa hasil putusan Pengadilan Negeri Surabaya yang diputuskan pada tahun 2020 itu tidak adil.

Berdasarkan latar belakang tersebut, peneliti akan membahas: Bagaimana tanggung jawab direksi terhadap perbuatan melawan hukum karyawan yang menetapkan diskon pembelian emas antam secara sepihak dikaitkan dengan Undang-Undang Perseroan Terbatas? Dan bagaimana penerapan prinsip Business Judgement Rule terhadap direksi yang harus bertanggung jawab atas perbuatan melawan hukum karyawan?

Adapun tujuan penelitian ini yaitu Pertama, untuk memahami tanggung jawab direksi terhadap perbuatan melawan hukum yang dilakukan karyawan dikaitkan dengan Undang-Undang Perseroan Terbatas. Kedua, untuk mengkaji penerapan prinsip Business Judgement Rules terhadap direksi yang harus bertanggungjawab atas perbuatan melawan hukum karyawan.

Metode pendekatan penelitian ini adalah yuridis normatif melalui pendekatan undang-undang (statute approach), pendekatan konseptual (conceptual approach) dan pendekatan kasus (case approach). Penelitian ini menggunakan dua macam sumber bahan hukum, yaitu bahan hukum primer dan bahan hukum sekunder. Bahan hukum primer didapat dari segala peraturan perundang-undangan yang terkait, yaitu KUHPerdata dan UUPT. Bahan sekunder didapat dari buku dan jurnal yang sesuai

\footnotetext{
${ }^{5}$ Fransiskus Simbolon, "Antam beberkan fakta penjualan ribuan kilogram emas ke pengusaha Budi Said", https://nasional.kontan.co.id/news/antam-beberkan-fakta-penjualan-ribuan-kilogram-emas-ke-pengusahabudi-said, diakses 01 Maret 2021 pukul 19.00 WIB.
} 
Dialogia luridica: Jurnal Hukum Bisnis dan Investasi

Volume 13 Nomor 1, November 2021

dengan topik pembahasan. Adapun teknik pengumpulan data dilakukan dengan penelitian kepustakaan yang selanjutnya dianalisis dengan metode analisis kualitatif untuk melakukan telaah atas putusan pengadilan yang meminta pertanggungjawaban direksi atas kesalahan dari karyawannya berdasarkan bahan pustakan dan peraturan perundangundangan.

\section{PEMBAHASAN}

\section{Tanggung Jawab Direksi Terhadap Perbuatan Melawan Hukum Karyawan Yang Menetapkan Diskon Pembelian Emas Antam Secara Sepihak Dikaitkan Dengan Undang-Undang Perseroan Terbatas}

Perbuatan melawan hukum adalah suatu perbuatan atau tidak berbuat sesuatu yang mengakibatkan timbulnya kerugian bagi orang lain tanpa sebelumnya ada suatu hubungan hukum, kewajiban mana ditujukan terhadap setiap orang pada umumnya dan dengan tidak memenuhi kewajibannya tersebut dapat diminta suatu ganti rugi. ${ }^{6}$ Perbuatan Melawan Hukum diatur dalam Pasal 1365 sampai dengan Pasal 1380 KUH Perdata. Pasal 1365 menyatakan, bahwa setiap perbuatan yang melawan hukum yang membawa kerugian kepada orang lain menyebabkan orang karena salahnya menerbitkan kerugian mengganti kerugian tersebut. Unsur kerugian dari suatu perbuatan melawan hukum merupakan dasar yang logis untuk timbulnya tanggung jawab untuk pelaku. Jika pelaku terbukti melakukan perbuatan melawan hukum, maka pelaku dapat dibebani kewajiban. ${ }^{7}$

Perbuatan melawan hukum tidak dapat dipisahkan dengan adanya pelanggaran hak oleh seseorang. Hak dalam pengertian perbuatan melawan hukum adalah suatu kewenangan yang diberikan oleh hukum terhadap seseorang dengan menutup orang lain atas hak tersebut. Suatu perbuatan dapat dikatakan melawan hukum apabila perbuatan tersebut bertentangan dengan hak subjektif orang lain, bertentangan dengan kewajiban hukum si pelaku, bertentangan dengan kesusilaan dan kepatutan. ${ }^{8}$ Sebagai konsekuensi adanya perbuatan melawan hukum, pasti akan muncul yang namanya tanggung jawab.

Tanggung jawab merupakan keadaan untuk menanggung segala sesuatu yang menjadi akibat dari sebuah perbuatan, baik yang dilakukan oleh perorangan atau badan hukum. Berbicara tentang perusahaan, tanggung jawab diletakkan pada organ perusahaan.

Pasal 1365 KUHPerdata merumuskan bahwa setiap orang bertanggung jawab tidak saja untuk kerugian yang disebabkan perbuatannya, tetapi juga untuk kerugian yang disebabkan kelalaian atau kurang hati-hati. Pasal 1367 KUHPerdata juga memberikan rumusan tanggung jawab yang lebih rinci. Kedua ketentuan KUHPerdata tersebut memberikan 2 (dua) kategori terhadap bentuk tanggung jawab. Pertama, tanggung jawab berdasarkan kesalahan, artinya seseorang dapat dimintai pertanggung jawaban atas

\footnotetext{
${ }^{6}$ Rachmat Setiawan, Tinjauan Elementer Perbuatan Melanggar Hukum, Bandung: Alumni, 1982, hlm. 7.

${ }^{7}$ Bachmid M., "Liability of The Holding Company for Unlawful Actions In Group Companies", Unram Law Review 5, No. 1, 2021, hlm. 133.

${ }^{8}$ Salam S., "Perkembangan Doktrin Perbuatan Melawan Hukum Penguasa", Jurnal Nurani Hukum 1, No. 1, 2018, hlm. 31 .
} 
kesalahan yang telah diperbuatnya dan akibat kesalahannya itu telah menimbulkan kerugian bagi orang lain. Kedua, tanggung jawab berdasarkan risiko, artinya seseorang dapat dimintai pertanggung jawaban atas kerugian yang diderita oleh orang lain bukan karena kesalahan yang bersangkutan, melainkan sebagai resiko yang ditanggungnya karena kesalahan orang lain dan orang tersebut menjadi bawahannya atau menjadi tanggungannya, atau dalam pengawasannya. ${ }^{9}$ Penelitian ini lebih memfokuskan pada tanggung jawab yang diemban oleh direksi berdasarkan kategori yang kedua yaitu tanggung jawab berdasarkan risiko, yaitu tanggung jawab direksi Antam atas kesalahan karyawan yang menetapkan diskon secara sepihak.

Tanggung jawab direksi tidak hanya terbatas pada ketidakjujuran yang disengaja tetapi juga tanggungjawab dalam kesalahan manajemen, kelalaian, kegagalan atau melakukan sesuatu yang tidak penting bagi perseroan. Iktikad baik direksi dapat dilihat ketika direksi benar-benar mementingkan kepentingan perseroan, shareholder, dan stakeholder. Tujuan yang benar dijalankan dengan mentaati AD/ART PT dan peraturan perundang-undangan. ${ }^{10}$ Direksi harus bertindak secara hati-hati, patut atau sebaikbaiknya sesuai dengan kewenangan yang diberikan dalam anggaran dasar. Seandainya dalam pengurusan dan perwakilan Perseroan tersebut direksi melakukan perbuatan atau tindakan yang melanggar batas kewenangan atau sesuatu ketentuan yang telah ditetapkan dalam anggaran dasar, kepadanya dapat dimintai pertanggungjawaban secara pribadi oleh pihak ketiga, baik sendiri-sendiri maupun bersama-sama untuk seluruhnya. Perseroan tidak bertanggung jawab atas perbuatan direksi yang melampaui wewenang yang diberikan anggaran dasar kepadanya. Kerugian yang diderita pihak ketiga bukan menjadi tanggung jawab Perseroan, melainkan menjadi tanggung jawab pribadi dari direksi seluruhnya.

Direksi sebagai organ perusahaan, selain tunduk pada KUHPerdata juga tunduk terhadap UUPT. Pengaturan direksi diatur dalam Bab VII Undang-Undang Nomor 40 Tahun 2007 tentang Perseroan Terbatas, dari Pasal 92 hingga Pasal 107. Menurut Pasal 97 ayat (2) UUPT, setiap anggota direksi bertanggung jawab penuh secara pribadi atas kerugian perseroan apabila yang bersangkutan bersalah atau lalai dalam menjalankan tugasnya. Apabila direksi terdiri dari atas 2 (dua) anggota direksi atau lebih, tanggung jawab sebagaimana dimaksud diatas, berlaku secara tanggung renteng bagi setiap anggota direksi. Namun berdasarkan Pasal 97 ayat (3) UUPT, anggota direksi tidak dapat dipertanggungjawabkan atas kerugian sebagaimana yang dimaksud diatas, apabila dapat membuktikan:

1. Kerugian tersebut bukan karena kesalahan atau kelalaiannya;

2. Telah melakukan pengurusan dengan iktikadbaik dan kehati-hatian untuk kepentingan dan sesuai dengan maksud dan tujuan Perseroan;

\footnotetext{
${ }^{9}$ Devi R. S., "Status hukum dan tanggung jawab anak perusahaan PT (perseroan terbatas) dalam suatu kelompok perusahaan", Jurnal ilmiah kohesi Vol. 4, no. 1, 2020, hlm. 92.

${ }^{10}$ Isfardiyana, "Tanggung Jawab Direksi Perseroan Terbatas dalam Pelanggaran Fiduciary Duty", Padjadjaran Journal of Law Vol. 2, no. 1, 2015, hlm. 8.
} 
Dialogia luridica: Jurnal Hukum Bisnis dan Investasi

Volume 13 Nomor 1, November 2021

3. Tidak mempunyai benturan kepentingan baik langsung maupun tidak langsung atas tindakan pengurusan yang mengakibatkan kerugian; dan

4. Telah mengambil tindakan untuk mencegah timbul atau selanjutnya kerugian tersebut.

Hal ini juga tercantum dalam Pasal 3 Ayat (2) UUPT bahwa pemegang saham perseroan bertanggungjawab secara pribadi atas kerugian perseroan apabila : pemegang saham yang bersangkutan baik langsung maupun tidak langsung dengan iktikadburuk memanfaatkan perseroan untuk kepentingan pribadi, pemegang saham yang bersangkutan terlibat dalam perbuatan melawan hukum yang dilakukan oleh perseroan, atau pemegang saham yang bersangkutan baik langsung maupun tidak langsung secara melawan hukum menggunakan kekayaan perseroan, yang mengakibatkan kekayaan perseroan menjadi tidak cukup untuk melunasi utang perseroan. Kecuali apabila pemegang saham tidak terbukti terlibat dalam perbuatan melawan hukum yang dilakukan direksi. Walaupun sebetulnya pasal tersebut diperuntukan untuk hubungan antara direksi dengan pemegang saham, namun terhadap direksi yang tidak terlibat secara langsung atas kerugian akibat perbuatan yang dilakukan oleh karyawan, maka terhadap direksi tersebut tidak bisa dimintai pertanggungjawaban.

Putusan Pengadilan Negeri Surabaya dengan nomor perkara 158/Pdt.G/2020/PN Sby, telah menjatuhkan putusannya kepada direksi PT. Antam untuk bertanggung jawab atas segala tindakan yang dilakukan oleh para karyawannya yang menawarkan diskon secara sepihak, seolah-olah mengatasnamakan perusahaan. Direksi PT. Antam dihukum untuk membayar ganti rugi kepada Penggugat yaitu Budi Said sebagai pembeli emas sebesar 817,46 miliar rupiah atau menyerahkan emas seberat 1.136 kilogram. Selain itu, hakim menghukum direksi PT. Antam dan Eksi Anggraeni selaku broker secara tanggung renteng untuk membayar kerugian immateriil kepada penggugat sebesar 500 miliar rupiah. $^{11}$

Dalam kasus posisi, penawaran diskon merupakan ide dari seorang broker bernama Eksi Anggraeni yang bekerjasama dengan dua oknum karyawan Antam yaitu Misdianto dan Ahmad Purwanto. Budi Said selaku konsumen, melakukan kesepakatan untuk mendapatkan diskon harga emas seberat 7 ton dengan nilai Rp3,5 triliun. Pembelian emas dilakukan oleh Eksi Anggraeni selaku penerima kuasa dari Budi Said dan secara rutin memberikan faktur serta barang kepada Budi Said. Padahal, Antam selalu memberi tahukan harga kepada konsumen lewat situs resmi www.logammulia.com, dan untuk harga komoditas tidak pernah ada yang namanya diskon. Budi Said mengaku sudah membayar dengan nominal sesuai kesepakatan, namun hanya menerima emas seberat 5,935 ton. Jumlah itu setara dengan pembelian emas dengan harga resmi yang berlaku saat itu. Menurut Budi Said hal itu tidak sesuai kesepakatan harga diskon yang dijanjikan

11 Tahir Saleh, "Antam vs Budi Said, Begini Kronologi Gugatan 1,1 Ton Emas", https://www.cnbcindonesia.com/market/20210118111618-17-216762/antam-vs-budi-said-beginikronologi-gugatan-11-ton-emas, diakses 02 Maret 2021 pukul 19.00 WIB. 
Dialogia luridica: Jurnal Hukum Bisnis dan Investasi

Volume 13 Nomor 1, November 2021

dengan broker. Budi kemudian mengambil langkah hukum setelah tak kunjung mendapatkan sisa emas, baik dari broker atau ketika meminta langsung ke pihak Toko Antam Surabaya.

Menurut penulis apabila dilihat dari kasus posisi yang dilakukan karyawan, direksi PT. Antam tidak dapat dimintai pertanggungjawaban secara penuh sesuai ketentuan Pasal 97 ayat (2) UUPT. Karena kerugian yang dialami konsumen tersebut bukan karena kesalahan atau kelalaian dari direksi PT. Antam. Kerugian yang terjadi murni atas perbuatan melawan hukum yang dilakukan oleh karyawan karena menetapkan harga diskon secara sepihak, dengan tidak mengindahkan SOP perseroan. Direksi PT. Antam telah melakukan pengurusan dengan iktikad baik dan kehati-hatian untuk kepentingan dan sesuai dengan maksud dan tujuan perseroan.

Di Indonesia menurut ketentuan hukum yang berlaku, gugatan perdata dilakukan apabila terjadinya wanprestasi atau perbuatan yang melanggar hukum. Kedua hal tersebut ada dalam ketentuan Buku III KUH Perdata Pasal 1243 dan Pasal 1365. ${ }^{12}$ Tentunya menjadi perhatian konsumen apabila terjadi kerugian harus diperhatikan siapa orang yang wajib bertanggungjawab.

Mengacu Pasal 1367 KUHPerdata bahwa seorang tidak saja bertanggung jawab untuk kerugian yang disebabkan perbuatannya sendiri, tetapi juga untuk kerugian yang disebabkan perbuatan orang-orang yang menjadi tanggungannya atau disebabkan oleh barang-barang yang berada di bawah pengawasannya. Tentunya direksi PT Antam mempunyai hubungan hukum dengan Wisdianto dan Ahmad Purwanto sebagai karyawannya. Perlu dipertegas kalimat berada di bawah pengawasannya, artinya direksi bertanggung jawab untuk kerugian sebatas perbuatan karyawan ada dalam pengawasan direksi atau direksi mengetahui perbuatan karyawan tersebut.

Dilihat dari Pasal 97 ayat (3) UUPT, direksi PT. Antam tidak dapat dipertanggung jawabkan atas kerugian yang dialami Budi Said. Kerugian yang dialami Budi Said bukan karena kesalahan atau kelalaian dari direksi. Seharusnya tuntutan ganti rugi hanya ditujukan kepada Eksi Anggraeni selaku broker dan kepada oknum karyawan saja.

\section{Penerapan Prinsip Business Judgement Rule Terhadap Direksi Yang Harus Bertanggungjawab Atas Perbuatan Melawan Hukum Karyawan}

Seperti telah diuraikan pada pembahasan sebelumnya bahwa tanggung jawab direksi hanya dilakukan apabila kerugian yang ditimbulkan merupakan kesalahan/kelalaian direksi. Untuk melindungi direksi dikenal suatu prinsip yaitu Prinsip Business Judgement Rule. Prinsip ini mengacu pada tugas untuk bertindak dengan iktikad baik dan dalam keyakinan yang jujur bahwa tindakan yang diambil adalah demi kepentingan terbaik perusahaan dan sesuai anggaran dasar. Black's Law Dictionary memberikan definisi Business Judgment Rule sebagai berikut:

\footnotetext{
12 Putri K. R. I., "Perlindungan Konsumen dalam Jual Beli Emas Melalui Platform Digital 'Tamasia'", Acta Comitas: Jurnal Hukum Kenotariatan, Vol. 4 No. 3, 2019, hlm. 467.
} 
Dialogia luridica: Jurnal Hukum Bisnis dan Investasi

Volume 13 Nomor 1, November 2021

"The presumption that in making business decisions not involving direct self interest or self dealing, corporate direction act on an informed basis, in good faith, and in honest belief that their actions are in the corporation "s best interest. The rule shields director and officer from liability for unprofitable or harmful corporate transactions if the transactions were mad in good faith, with due care and within the director or officer authority."13

Ridwan Khairandy mengartikan Business Judgment Rule sebagai doktrin yang mengajarkan bahwa direksi perseroan tidak bertanggung jawab atas kerugian yang timbul dari suatu tindakan pengambilan putusan, apabila tindakan tersebut didasarkan pada iktikad baik dan hati-hati. ${ }^{14}$

Sutan Remi Syahdeni mengartikan Business Judgement Rule adalah prinsip untuk melindungi direksi dari tugas dan tanggungjawab yang dipikulnya. Jika direksi tersebut berhak atas perlindungan hukum maka pengadilan tidak berhak mencampuri atas putusan yang diambilnya tersebut, namun sebaliknya jika tidak berhak atas perlindungan hukum atas putusan yang telah diambilnya maka pengadilan wajib memeriksa putusan tersebut apakah terdapat kejujuran yang mendasar dan ittikad baik kepada perusahaan dan pemegang saham minoritas serta harus dilakukan tanpa selffialing, tidak dilakukan untuk kepentingan pribadi dan harus dengan iktikad baik. ${ }^{15}$

Prinsip Business Judgement Rule dapat dipahami sebagai standar pemberlakukan kebijakan perilaku bagi administrator, berdasarkan yang harus dinilai tanggung jawabnya. Namun, harus diingat bahwa prinsip ini tidak hanya diterapkan dalam penilaian eks-pos perilaku direksi dalam kinerja fungsinya, tetapi dapat digunakan, dan seringkali berlangsung dalam evaluasi sebelum kegiatan dilakukan mengenai permintaan perintah yang bertujuan menghambat pelaksanaan tindakan manajemen. ${ }^{16}$ Dalam mengambil suatu kebijakan, maka pengurus Perseroan perlu meminta kajian secara internal apakah ada risiko-risiko yang mungkin bisa timbul: dari risiko paling tinggi (high risk) sampai paling rendah (low risk), aspek-aspek lainnya seperti legal, kepatuhan, dan lain sebagainya. Misalnya, berdasarkan hasil pengkajian internal tersebut, apabila pengurus Perseroan tidak mengambil keputusan atas kebijakan itu, perseroan bisa terancam pailit, atau risiko yang yang akan dihadapinya lebih besar, dan lain sebagainya maka hal inilah

13 Terjemahan bebas: Anggapan bahwa dalam membuat keputusan bisnis tidak melibatkan kepentingan pribadi atau berdagang sendiri, direksi korporasi bertindak berdasarkan informasi yang cukup dan dalam keyakinan yang jujur bahwa tindakan mereka adalah demi kepentingan terbaik korporasi. Ketentuan Business Judgment Rule membentengi direksi dan pejabatnya dari tanggung jawab atas transaksi yang berbahaya atau tidak menguntungkan, jika transaksi itu dilakukan dengan iktikadbaik, dengan hati-hati yang layak dan dalam kewenangan direksi atau pejabat itu.

14 Ridwan Khairandy, Perseroan Terbatas, Doktrin, Peraturan Perundang-undangan, dan Yurisprudensi, Cet.2, Yogyakarta: Kreasi Total Media, 2009, hlm. 212.

${ }^{15}$ Sutan Remi Syahdeni, Tanggung Jawab Direksi dan Komisaris. Jakarta: Pustaka Yustisia, 2011, hlm. 78.

16 Giovine Francesco, “La business judgement rule: un'analisi comparatistica”, Thesis Luiss Guido Carli, 2017, hlm. 207. 
yang menjadi dasar keputusan untuk memutuskan suatu kebijakan. Keputusan seperti ini termasuk termasuk salah satu alasan pembenar atas kebijakan pengurus Perseroan. ${ }^{17}$

Prinsip Business Judgement Rule memberikan dorongan bagi direksi untuk tidak perlu takut terhadap ancaman tanggung jawab pribadi dalam menjalankan tugasnya. Business Judgement Rule dimaksudkan untuk mendorong direksi lebih berani mengambil risiko ketimbang terlalu hati-hati. Prinsip tersebut juga mencerminkan asumsi bahwa pengadilan tidak dapat membuat keputusan yang lebih baik dalam bidang bisnis ketimbang direksi. Pengadilan harus menghormati keputusan bisnis yang diambil oleh orang-orang yang mengerti dan berpengalaman di bidang bisnisnya. Masalah-masalah bisnis yang kompleks membutuhkan kecepatan penangan dan penyelesaian. Dengan demikian seharusnya pengadilan selain mempertimbangkan ketentuan hukum, pengadilan juga harus mempertimbangkan manfaat ekonomis dan keadaan sosial perusahaan. ${ }^{18}$

Direksi adalah pihak yang paling berkompeten untuk menjalankan dan memutuskan terhadap bisnis perusahaan, maka tidak ada satu orang pun yang berwenang memberi keputusan tentang bisnis perseroan. Bahkan pengadilan pun tidak boleh memberikan pendapat bandingan (second guess) terhadap putusan bisnis dari direksi tersebut. ${ }^{19}$ Hal ini didasari pada pemikiran prinsip Business Judgement Rule Amerika Serikat sebagai permulaan munculnya absention doctrine dengan pemahaman bahwa hakim tidak mempunyai cukup pengetahuan dibidang bisnis, sehingga tidak layak untuk memeriksa keputusan direksi. Karena itu gugatan terhadap direksi dalam hubungan dengan putusan bisnisnya dengan berdalilkan kelirunya putusan direksi, sering kali ditolak oleh pengadilan berdasarkan doktrin putusan bisnis ini meskipun kepada direksi dibebankan fiduciary duty yang membebankan tanggung jawab yang besar. ${ }^{20}$

Berbeda bagi negara-negara civil law system yang sumber hukum terletak pada peraturan perundang-undangan, maka pengadilan bertugas untuk melakukan interpretasi terhadap doktrin tersebut yang disebabkan oleh belum adanya pengaturan yang secara komprehensif, jelas dan spesifik mengenai prinsip Business Judgement Rule. Prinsip ini timbul sebagai akibat telah dilaksanakannya kewajiban sebagai direksi dengan penuh tanggungjawab (fiduciary duty) oleh seorang direksi, yang didalamnya termasuk pelaksanaan atas duty of skill and care. ${ }^{21}$

Hubungan fiduciary terjadi ketika ketika satu pihak berbuat sesuatu bagi kepentingan pihak lain dengan mengesampingkan kepentingan pribadinya sendiri.

\footnotetext{
${ }^{17}$ Ariyadi F., "Penerapan Business Judgement Rules Dalam Badan Usaha Milik Negara Studi Kasus PT Asuransi Jiwasraya", Indonesian Journal of Law and Policy Studies, Vol. 1 No. 1, 2020, hlm. 71.

${ }^{18}$ Pramagitha P. A dan Sukranatha A. K, "Prinsip business judgment rule sebagai upaya perlindungan terhadap keputusan bisnis direksi bumn", Kertha Semaya: Journal Ilmu Hukum, Vol. 7 No. 12, 2019, hlm. 12 .

${ }^{19}$ Lestari S. N., "Business Judgment Rule Sebagai Immunity Doctrine Bagi Direksi Badan Usaha Milik Negara di Indonesia”, Notarius, Vol. 8 No. 2, 2015, hlm. 302. ${ }^{20}$ Ibid

${ }^{21}$ Hendra Setiawan Boen, Bianglala Business Judgment Rule, Jakarta: Tatanusa, 2008, hlm. 100.
} 
Dialogia luridica: Jurnal Hukum Bisnis dan Investasi

Volume 13 Nomor 1, November 2021

Fiduciary Duty merupakan salah satu asas hukum yang dikenal dalam hukum perusahaan. Menurut asas ini, direksi harus memiliki prinsip sebagai berikut:

1. Direksi dalam melakukan tugasnya tidak boleh melakukannya untuk kepentingan pribadi ataupun kepentingan pihak ketiga tanpa persetujuan dan atau sepengetahuan perseroan;

2. Direksi tidak boleh memanfaatkan kedudukannya sebagai pengurus untuk memperoleh keuntungan, baik untuk dirinya sendiri maupun pihak ketiga kecuali atas persetujuan perseroan;

3. Direksi tidak boleh menggunakan atau menyalahgunakan aset perseroan untuk kepentingannya sendiri dan atau pihak ketiga. ${ }^{22}$

Pada umumnya, Fiduciary Duty dibagi menjadi dua komponen utama, yaitu Duty of Care dan Duty of Loyalty. Pada Duty of Care, direksi diharuskan untuk bertindak dengan kehati-hatian dalam membuat segala keputusan dan kebijakan perseroan. Setiap kebijakan, direksi harus tetap mempertimbangkan segala informasi-informasi yang ada secara patut dan wajar. Kemudian Duty of Loyalty, direksi bertanggung jawab untuk selalu berpihak kepada kepentingan perusahaan yang dipimpinnya. Direksi yang diberikan kepercayaan oleh perseroan harus bertindak untuk kepentingan pemegang saham, bertindak untuk kepentingan dan tujuan perseroan, serta bertindak dengan mengutamakan kepentingan perseroan diatas kepentingan pribadi. ${ }^{23}$

Fiduciary Duty tentunya digunakan direksi agar terhindar dari kesalahan. Ada toleransi terhadap kesalahan dari direksi atas suatu perseroan hanya sampai kepada batasbatas tertentu saja. Adapun kesalahan direksi yang dapat ditoleransi adalah sebagai berikut:

1. Hanya salah dalam mengambil putusan (mere error of judgement);

2. Kesalahan yang jujur (honest mistake, honest error in judgement);

3. Kerugian perusahaan karena kesalahan karyawan perusahaan (kecuali jika tidak ada sistem pengawasan yang baik). ${ }^{24}$

Berkaitan dengan hal ini, terhadap kerugian suatu perseroan yang diakibatkan kesalahan karyawan perseroan juga dapat menjadi dasar yang bisa mentoleransi kesalahan direksi untuk mendapat pembebasan tanggung jawab pribadinya, selama direksi telah melakukan pengawasan terhadap tindakan karyawannya. Selain hal tersebut adanya kekhilafan jujur atau prinsip keterbukaan (disclosure) secara formal dari direksi terhadap adanya benturan kepentingan direksi dalam membuat suatu perhitungan yang dapat menyebabkan kerugian bagi perseroan juga dapat dijadikan dasar untuk mengindikasikan adanya iktikad baik dari direksi. Dipenuhinya iktikad baik menjadi

\footnotetext{
${ }^{22}$ Bryan A. Garner, Black's Law Dictionary, St.Paull-Minn: West Publishing Co, 2004, hlm. 108.

${ }^{23}$ Ibid.

${ }^{24}$ Munir Fuady, Perseroan Terbatas Paradigma Baru, Bandung: Citra Aditya Bakti, 2003, hlm. 186.
} 
penting untuk direksi dalam pengambilan keputusan agar dapat memperoleh perlindungan berdasarkan prinsip Business Judgement Rule.

Direksi dalam melakukan suatu keputusan bisnis dapat dimintai pertanggungjawaban pribadi sepanjang terdapat keterlibatan dirinya yang menyebabkan kerugian pada perusahaan. Seperti telah dibahas sebelumnya, UUPT meletakan tanggung jawab pribadi direksi dalam pasal 97 ayat (3) UUPT yang membebankan direksi terhadap tanggung jawab pribadi apabila melanggar standar keputusan bisnis. Sebagai sanksinya, apabila direksi menyalahgunakan kedudukannya sebagai pemegang amanah perseroan atau apabila bersalah dalam menjalankan tugasnya yang mengakibatkan perseroan menderita kerugian, maka setiap anggota direksi bertanggung jawab secara pribadi. ${ }^{25}$

Prinsip Business Judgement Rule dapat dijadikan satu bentuk pembebasan tanggung jawab direksi karena kesalahannya yang mengakibatkan kerugian dengan satu catatan selama pelaksanaan kewenangannya telah menerapkan satu bentuk iktikad yang baik dan mengedepankan prinsip kehati-hatian. Prinsip Business Judgement Rule ini digunakan sebagai pengecualian bagi direksi yang berada pada posisi yang tidak terlindungi.

Praktek terkait prinsip Business Judgement Rule di Amerika telah banyak diadopsi oleh sejumlah pengadilan. Pada kasus Hodges v. New England Screw Co., pengadilan berpikir bahwa dewan direksi yang bertindak dengan iktikadbaik dari perhatiannya dan ketekunan yang wajar, namun jika direksi jatuh dalam kesalahan, baik secara hukum dan fakta, direksi tidak bertanggung jawab atas konsekuensi dari kesalahan tersebut". ${ }^{26}$ Di pengadilan yang berbeda, pada kasus Bodell v. General Gas \& Electric Corp., Mahkamah Agung Delaware menyatakan bahwa tindakan direktur yang telah dilaksanakan dengan iktikad baik, dan dalam penilaian terbaik mereka, serta untuk apa yang mereka yakini menguntungkan perusahaan dan semua pemegang sahamnya, tidak dapat disalahkan (Supreme Court of Delaware, 1927). ${ }^{27}$ Rumusan awal Business Judgement Rule ini yang kemudian ditegaskan lagi oleh Pengadilan Delaware dalam kasus Aronson v. Lewis, tahun 1984. Pernyataan dalam putusan ini adalah pernyataan yang paling banyak dirujuk oleh pengadilan lain dan berbagai kalangan, akademi dan praktisi, di Amerika. Dalam putusan ini, Business Judgement Rule didefinisikan sebagai: Business Judgement Rule adalah sebuah praduga bahwa dalam membuat sebuah keputusan bisnis, direktur perusahaan bertindak berdasarkan informasi, dengan iktikadbaik dan dengan keyakinan jujur bahwa tindakan yang diambil adalah demi permasalahan hukum dan kepentingan terbaik perusahaan. Jika tidak ada penyalahgunaan diskresi, keputusan itu akan dihormati

25 Elza Syarief, dan Attika Balqist, "Doktrin Fiduciary Duty dan Corporate Opportunity Terhadap Pertanggungjawaban Direksi dan Dewan Komisaris", Journal of Law and Policy Transformation, Vol. 2 No.2, 2018, hlm. 99.

26 Johnson O, "Business judgment v. audit judgment: Why the legal distinction?", Accounting, Organizations and Society, Vol. 17 No. 3, 1992, hlm. 209.

${ }^{27}$ Rissy Y. Y. W, "Ketentuan dan Pelaksanaan Business Judgement Rule di Amerika, Australia dan Indonesia", Masalah-Masalah Hukum, Vol. 49 No. 2, 2020, hlm. 162. 
oleh pengadilan. Beban ada pada pihak yang menentang keputusan untuk menetapkan fakta yang membantah anggapan tersebut (Supreme Court of Delaware, 1984). ${ }^{28}$

Di Indonesia, prinsip Business Judgement Rule juga telah diterapkan oleh hakim pada Putusan Mahkamah Agung terhadap direksi PT. Pertamina bernama Karen. Majelis Hakim menilai aksi Karen sebagai bentuk risiko bisnis. Perbedaan pandangan Karen pun tidak dipersoalkan sebagai upaya penyalahgunaan wewenang karena kewenangan keputusan ada pada direksi, bukan komisaris. Selain itu, Karen dan direksi sudah mendapat release and discharge untuk ikut lelang. Oleh sebab itu, hakim beranggapan bahwa karena tidak bersalah. ${ }^{29}$ merujuk pada kasus tersebut apabila terdapat kasus serupa maka sejatinya juga diterapkan prinsip Business Judgement Rule.

Penelitian sebelumnya yang juga membahas mengenai penerapan prinsip Business Judgement Rule terhadap direksi yaitu Kasus PT. ICI Paints Indonesia. Gugatan Penggugat yang menyatakan para Tergugat telah secara sewenang-wenang menetapkan remunerasi yang berlebihan kepada General Manager tanpa persetujuan seluruh anggota Direksi, ternyata tidak terbukti. Tindakan penetapan remunerasi General Manager tersebut adalah wajar karena sejalan dengan meningkatnya penghasilan PT ICI Paints Indonesia. Untuk itu tidak terbukti menyalahi Anggaran Dasar PT ICI Paints Indonesia ataupun Shareholders Agreement (yang dibuat diantara para pemegang saham PT ICI Paints Indonesia), maka tindakan tersebut bukanlah perbuatan melawan hukum sehingga direksi PT ICI Paints Indonesia dibebaskan dari segala dakwaan oleh Majelis Hakim. ${ }^{30}$ Berkaca dari Kasus PT ICI Paints Indonesia, tanggungjawab pribadi direksi dapat timbul jika keputusan yang diambil direksi tidak disertai pertimbangan yang matang dan tanpa memperhatikan iktikad baik yang harusnya dilakukannya sehingga menyebabkan perseroan merugi. Sementara apabila satu keputusan yang diambil oleh direksi merupakan keputusan yang diambil dengan berlandaskan prinsip iktikad yang baik namun tetap mengakibatkan perseroan merugi, maka direksi tetap tidak dapat dituntut atau diminta pertanggungjawabannya secara pribadi dikarenakan adanya perlindungan berdasarkan prinsip Business Judgement Rule.

Oleh karena itu, pada intinya Prinsip Business Judgement Rule secara tersirat bisa dilihat dari Pasal 92 Ayat (1) dan Pasal 97 Ayat (2),(3),(5) UUPT terkait kepentingan, maksud dan tujuan perseroan yang harus menjadi dasar kepengurusan dari direksi. Dalam melakukan pengurusan, direksi wajib melakukan dengan iktikad baik dan penuh tanggungjawab. Manakala muncul kerugian dan dapat dibuktikan oleh direksi bukan karena salahnya, maka direksi harus dibebaskan dari pertanggungjawaban pribadi. Alasan yang dapat membebaskan direksi dari pertanggungjawaban pribadi antara lain: 1)

\footnotetext{
28 Ibid.

29 Fana Suparman, "MA Vonis Bebas Mantan Dirut Pertamina Karen Agustiawan", https://www.beritasatu.com/nasional/607023/ma-vonis-bebas-mantan-dirut-pertamina-karen-agusti awan, diakses 08 April 2021 pukul 20.00 WIB.

${ }^{30}$ Noverisa Tria, "Penerapan Prinsip Business Judgement Rule bagi Direksi PT Penanaman Modal Asing Sebagai Pembelaan dalam Kerugian Perusahaan Berdasarkan Undang-Undang Nomor 40 Tahun 2007 Tentang Perseroan Terbatas", Tesis Universitas Sumatera Utara, 2019, hlm. 14.
} 
Dialogia luridica: Jurnal Hukum Bisnis dan Investasi

Volume 13 Nomor 1, November 2021

kerugian yang muncul bukan karena salah atau lalaianya direksi; 2) direksi telah melakukan pengurusan perusahaan dengan iktikad baik dan kehati-hatian; 3) direksi tidak memiliki benturan kepentingan atas tindakan pengurusan yang mengakibatkan kerugian; dan 4) direksi telah mengambil tindakan untuk mencegah timbul atau berlanjutnya kerugian.

Apabila ketentuan tersebut diterapkan dengan baik oleh hakim, sejatinya keadilan akan terwujud secara nyata. Keadilan adalah pengakuan dan perlakukan seimbang antara hak dan kewajiban. ${ }^{31}$ Tentunya hakim sebagai penegak hukum harus memperhatikan asas keadilan dalam setiap mempertimbangkan putusannya.

Berdasarkan penerapan prinsip Business Judgement Rule yang telah diterapkan, maka menurut penulis, putusan hakim yang mewajibkan PT. Antam mengganti kerugian atas perbuatan melawan hukum oleh karyawannya, belum menerapkan prinsip Business Judgement Rule. Diketahui dari keterangan direksi PT. Antam bahwa selama pengelolaan perusahaan, telah dilakukan pengawasan melalui sistem E-mas dan butik wajib memberikan laporan mengenai penjualan, konsolidasi bank dan berita acara stok opname harian yang sudah terverifikasi baik dalam aspek informasi maupun keuangan. Setiap laporan penjualan PT. Antam dibahas dalam rapat bulanan bersama dengan direktur operasional. Untuk skema penjualan, Antam memiliki SOP yang isinya pembelian dilakukan secara cash and carry, artinya hari itu pembeli membayar, maka hari itu juga menerima barang. ${ }^{32}$ Direksi PT. Antam selama ini telah melakukan manajemen perusahaan dengan baik dan memiliki iktikad baik. Adanya pengajuan banding yang dilakukan PT. Antam, sebagai bentuk mencari keadilan dan kepastian hukum. Mengingat konsep prinsip Business Judgement Rule, kedepannya diharapkan hakim dapat menerapkan prinsip Business Judgement Rule dalam melakukan pertimbangan hukum sebelum menghasilkan putusan.

Apabila merujuk pada beberapa putusan pengadilan baik di dalam maupun di luar negeri, seharusnya direksi dengan kasus seperti pada PT. Antam juga mendapatkan rasa keadilan yang merujuk pada prinsip Business Judgement Rule. Artinya, direksi PT. Antam seharusnya dibebaskan dari tanggung jawab mengganti kerugian kepada Budi Said sebagai pembeli emas dengan iming-iming diskon dari karyawannya. Pihak yang sejatinya dimintai pertanggung jawaban adalah karyawan bernama Misdianto dan Ahmad Purwanto, dan juga broker yaitu Eksi Anggraeni.

${ }^{31}$ Farida Sekti Pahlevi, "Revitalisasi Pancasila Dalam Penegakan Hukum Yang Berkeadilan di Indonesia", Justicia Islamica, Vol. 13 No.2, 2016, hlm.13.

${ }^{32}$ Lihat Putusan Pengadilan Negeri Surabaya Nomor 2576/Pid.B/2019/PN.Sby 
Dialogia luridica: Jurnal Hukum Bisnis dan Investasi

Volume 13 Nomor 1, November 2021

\section{PENUTUP}

Direksi PT. Antam tidak seharusnya dimintai pertanggung jawaban untuk ikut membayar ganti rugi kepada Budi Said karena kerugian yang dialami Budi Said sejatinya bukan karena kesalahan atau kelalaian dari direksi. Sudah jelas bahwa tanggung jawab ganti rugi seharusnya hanya dibebankan pada Eksi Anggraeni dan kedua oknum karyawan PT. Antam yaitu Midianto dan Ahmad Purwanto.

Penerapan prinsip Business Judgement Rule terhadap direksi yang harus bertanggung jawab atas perbuatan melawan hukum karyawan ternyata belum diterapkan oleh majelis hakim Pengadilan Negeri Surabaya. Seharusnya prinsip Business Judgement Rule dapat diterapkan oleh hakim, karena pentingnya perlindungan hukum tidak hanya diletakkan bagi konsumen saja. Sebetulnya, direksi PT. Antam juga dapat disebut sebagai korban atas perbuatan melawan hukum yang dilakukan oleh karyawannya. Direksi PT. Antam dalam menjalankan perseroan telah melakukan pengurusan dengan iktikad baik dan penuh tanggung jawab. Dengan demikian, direksi PT. Antam selayaknya mendapatkan perlindungan hukum sesuai dengan konsep pada prinsip Business Judgement Rule. Direksi PT. Antam dapat menempuh jalur hukum banding ke Pengadilan yang lebih tinggi sebagai wujud memperjuangkan keadilan atas putusan hakim tingkat pertama yang menuntut direksi bertanggung jawab atas perbuatan yang tidak dilakukannya.

\section{DAFTAR PUSTAKA}

\section{Buku}

Bryan A. Garner, Black's Law Dictionary, St.Paull-Minn: West Publishing Co, 2004.

Gunawan Widjaja, 150 Tanya Jawab tentang Perseroan Terbatas, Jakarta: Forum Sahabat, 2008.

Hendra Setiawan Boen, Bianglala Business Judgment Rule, Jakarta: Tatanusa, 2008.

Rachmat Setiawan, Tinjauan Elementer Perbuatan Melanggar Hukum, Bandung: Alumni, 1982.

Munir Fuady, Perseroan Terbatas Paradigma Baru, Bandung: Citra Aditya Bakti, 2003. Ridwan Khairandy, Perseroan Terbatas, Doktrin, Peraturan Perundang-undangan, dan Yurisprudensi, Cet.2, Yogyakarta: Kreasi Total Media, 2009.

Sutan Remi Syahdeni, Tanggung Jawab Direksi dan Komisaris. Jakarta: Pustaka Yustisia, 2011.

\section{Jurnal}

Ariyadi F., "Penerapan Business Judgement Rules Dalam Badan Usaha Milik Negara Studi Kasus PT Asuransi Jiwasraya", Indonesian Journal of Law and Policy Studies, Vol. 1 No. 1, 2020.

Bachmid M., "Liability of The Holding Company for Unlawful Actions In Group Companies", Unram Law Review 5, No. 1, 2021. 
Dialogia luridica: Jurnal Hukum Bisnis dan Investasi

Volume 13 Nomor 1, November 2021

Devi R. S., "Status hukum dan tanggung jawab anak perusahaan PT (perseroan terbatas) dalam suatu kelompok perusahaan”, Jurnal Ilmiah Kohesi, Vol. 4 No. 1, 2020.

Elza Syarief, dan Attika Balqist, "Doktrin Fiduciary Duty dan Corporate Opportunity Terhadap Pertanggungjawaban Direksi dan Dewan Komisaris", Journal of Law and Policy Transformation, Vol. 2 No.2, 2018.

Farida Sekti Pahlevi, "Revitalisasi Pancasila Dalam Penegakan Hukum Yang Berkeadilan di Indonesia", Justicia Islamica, Vol. 13 No.2, 2016

Isfardiyana, "Business Judgement Rule Oleh Direksi Perseroan", Jurnal Panorama Hukum Vol. 2 No. 1, 2017.

Isfardiyana, "Tanggung Jawab Direksi Perseroan Terbatas dalam Pelanggaran Fiduciary Duty", Padjadjaran Journal of Law, Vol. 2 No. 1, 2015.

Johnson O, "Business judgment v. audit judgment: Why the legal distinction?", Accounting, Organizations and Society, Vol. 17 No. 3, 1992.

Lestari R, et.al, "Konsistensi Pengukuhan Kedudukan Kekayaan Negara Yang Dipisahkan Pada Badan Usaha Milik Negara Menurut Pelaku Kekuasaan Kehakiman Dalam Kaitannya Dengan Doktrin Business Judgement Rule", ACTA DIURNAL Jurnal Ilmu Hukum Kenotariatan Vol. 1, no. 2, 2018.

Lestari S. N., "Business Judgment Rule Sebagai Immunity Doctrine Bagi Direksi Badan Usaha Milik Negara di Indonesia", Notarius, Vol. 8 No. 2, 2015.

Putri K. R. I., "Perlindungan Konsumen dalam Jual Beli Emas Melalui Platform Digital 'Tamasia'”, Acta Comitas: Jurnal Hukum Kenotariatan, Vol. 4 No. 3, 2019.

Pramagitha P. A dan Sukranatha A. K, "Prinsip business judgment rule sebagai upaya perlindungan terhadap keputusan bisnis direksi bumn", Kertha Semaya: Journal Ilmu Hukum, Vol. 7 No. 12, 2019.

Rissy Y. Y. W, "Ketentuan dan Pelaksanaan Business Judgement Rule di Amerika, Australia dan Indonesia", Masalah-Masalah Hukum, Vol. 49 No. 2, 2020.

Salam S., "Perkembangan Doktrin Perbuatan Melawan Hukum Penguasa", Jurnal Nurani Hukum 1, No. 1, 2018.

\section{Thesis}

Giovine Francesco, "La business judgement rule: un'analisi comparatistica", Thesis Luiss Guido Carli, 2017.

Noverisa Tria, "Penerapan Prinsip Business Judgement Rule bagi Direksi PT Penanaman Modal Asing Sebagai Pembelaan dalam Kerugian Perusahaan Berdasarkan Undang-Undang Nomor 40 Tahun 2007 Tentang Perseroan Terbatas", Tesis Universitas Sumatera Utara, 2019.

\section{Peraturan Perundang-Undangan}

Kitab Undang-Undang Hukum Perdata

Undang-Undang Nomor 40 Tahun 2007 Tentang Perseroan Terbatas. 
Dialogia luridica: Jurnal Hukum Bisnis dan Investasi

Volume 13 Nomor 1, November 2021

\section{Pranala Luar}

Fana Suparman, MA Vonis Bebas Mantan Dirut Pertamina Karen Agustiawan, https://www.beritasatu.com/nasional/607023/ma-vonis-bebas-mantan-dirutpertamina-karen-agusti awan, diakses 08 April 2021 pukul 20.00 WIB.

Fransiskus Simbolon, Antam beberkan fakta penjualan ribuan kilogram emas ke pengusaha Budi Said, https://nasional.kontan.co.id/news/antam-beberkan-faktapenjualan-ribuan-kilogram-emas-ke-pengusaha-budi-said, diakses 01 Maret 2021 jam 19.00 WIB.

Saleh Tahir, Antam vs Budi Said, Begini Kronologi Gugatan 1,1 Ton Emas, https://www.cnbcindonesia.com/market/20210118111618-17-216762/antam-vsbudi-said-begini-kronologi-gugatan-11-ton-emas, diakses 02 Maret 2021 jam 19.00 WIB. 